\title{
ASPHIO President's Award 2013
}

\section{Ralph Stanley and Andrew Papadopoulos}

Ron de Burger was the well deserved recipient of the ASPHIO President's Award at the Association of Supervisors of Public Health Inspectors of Ontario (ASPHIO) meetings in Blue Mountain, Ontario, on 3 June 2013.

The ASPHIO President's Award is presented annually to recognize members with special distinction who make a significant contribution to public health. The award is presented to the member who, in the opinion of the ASPHIO Executive, has displayed the highest leadership standards of professional practice during the previous year.

To be eligible for consideration for the ASPHIO President's Award, the nominee must be a Member in Good Standing of ASPHIO and the Canadian Institute of Public Health Inspectors (CIPHI). The member must demonstrate a significant contribution to the advancement of environmental public health, and (or) their community, and (or) promotion of the professional standards of environmental public health, and

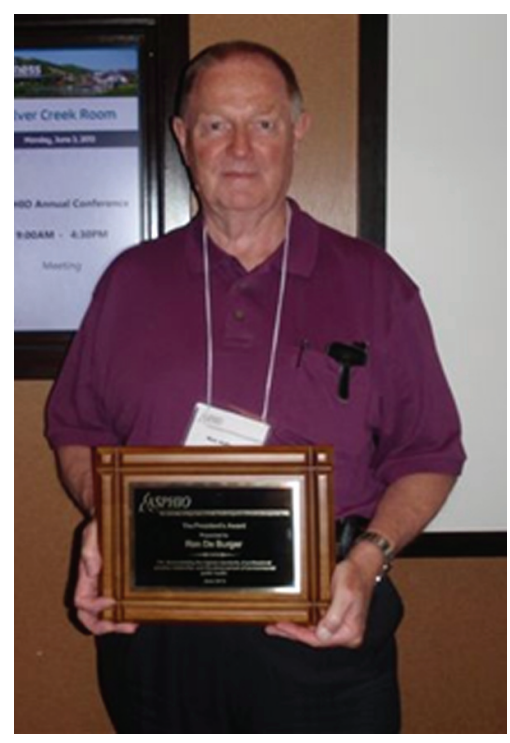

ASPHIO President's Award recipient Ron de Burger. (or) express exemplary leadership in dealing with a critical issue affecting public health. Ron is an icon in public health.

Ron has been involved in public health in Canada for nearly 50 years. He has had extensive experience as a public health inspector and as a teacher and academic administrator at the college and university level. He has served as the Assistant Deputy Minister, Preventive Services in British Columbia and as a Senior Consultant in the Health Protection Branch at Health Canada. As Toronto Public Health's Director of Healthy Environments, he has advanced the leadership, knowledge exchange, and governance of programs in Food Safety, Water Safety, Health Hazard Investigation, Emergency Response, and Tobacco Control for Canada's largest urban health department.

Ron has been active as a volunteer and professional staff member in several nongovernmental associations, and he has held elected leadership positions in each of those. Ron served as National President for four years with CIPHI and is also a Life Member of CIPHI. Ron is a Past-Chair of the Canadian Public Health Association (CPHA), and was a member of the National Executive for CPHA.

Ron serves as the Chair of the Board of Trustees of the Environmental Health Foundation of Canada. He is a member of the Advisory Board to the National Collaborating Centre for Environmental Health and the Advisory Council for the National Collaborating Centers for Public Health, and Ron is an Honorary Member of the Ontario Public Health Association (OPHA).

Ron has worked with colleagues in different public health areas and has become active in advocacy initiatives at both the provincial and national level. Ron aspires to bring together leading professionals to share the best available information and expertise to engage in effective advocacy for significant public health policy topics and for the betterment of ASPHIO and public health inspectors alike.

Ron de Burger's outstanding leadership in the public health field at the international, national, provincial, and community levels has significantly impacted and influenced the field of public health in Canada today.

Congratulations Ron! 